Brit. Heart J., 1965, 27, 697.

\title{
PATHOLOGY OF THE HEART WITH AND WITHOUT CARDIAC FAILURE IN THE AGED
}

\author{
BY \\ ARIELA POMERANCE* \\ From the Department of Morbid Anatomy and Histology, Central Middlesex Hospital, Park Royal, \\ London N.W.10
}

Received December 18, 1964

According to the Registrar General's Review for 1962 (General Register Office, 1964) half the deaths from diseases of the circulatory system occur in patients over 75 years of age yet little is known of the pathology of the heart in the elderly. Recent clinical reviews (Caird, 1963; Lancet, 1963) emphasize the importance of this subject, but though information on the general morbid anatomy of old age is accumulating (Howell, 1963), little detailed work on cardiovascular pathology is at present available. Cardiovascular disease accounts for over 40 per cent of deaths over 75 years, and with the increasing life span of the population, the problem of heart disease in the elderly is one of growing importance. At the same time the quantity of pathological material available for study is also increasing. The routine necropsies in this hospital over a 22 -month period have included 370 patients over 75 years of age, and this communication describes the results of detailed studies of their hearts. Findings in patients with cardiac failure are compared with those in patients with clinically normal cardiovascular systems, and the part played by the various abnormalities, and by multiple pathology, in the pathogenesis of cardiac failure in the elderly is discussed.

\section{MATERIALS AND MeTHODS}

The 370 hearts studied were obtained from the routine necropsy material of this hospital over a 22-month period, and included almost all patients dying over the age of 75 who had been admitted as acute medical or surgical emergencies or into the geriatric wards. It was not possible to include cases where necropsy was performed on the instruction of H.M. Coroner, but the material was otherwise unselected.

Following the routine necropsies, performed by any of the pathologists of this department, a further detailed examination of all adult hearts was carried out by the author personally, as part of a research project into various aspects of geriatric heart disease. All hearts showing abnormalities of valves or endocardium, however minor, were fixed whole, re-examined after fixation, and suitable blocks were taken for histological examination. In addition, all hearts from patients over 80 years of age, as well as representative numbers of younger age-groups were also fixed and re-examined grossly and microscopically and the findings were recorded.

Details of non-cardiac pathology and the heart weights were obtained from the necropsy reports; the clinical findings were those of the physician or surgeon in charge of the case at each admission, and reports of cardiographic findings, special investigations, and therapy were also obtained from the case notes.

The patients were divided into four age-groups: 75-79 years, 80-84, 85-89, and 90 and over, and the findings in those with cardiac failure compared with those with clinically normal cardiovascular systems, in

* In receipt of a grant from the North West Metropolitan Regional Hospital Board. 
TABLE I

Distribution of 370 Cases by Age-Group and SeX

\begin{tabular}{|c|c|c|c|c|c|c|c|c|c|c|c|}
\hline & & \multicolumn{2}{|c|}{ All cases } & \multicolumn{2}{|c|}{$75-79$ years } & \multicolumn{2}{|c|}{$80-84$ years } & \multicolumn{2}{|c|}{$85-89$ years } & \multicolumn{2}{|c|}{ Over 90 years } \\
\hline & & Failure & $\begin{array}{l}\text { Non- } \\
\text { failure }\end{array}$ & Failure & $\begin{array}{l}\text { Non- } \\
\text { failure }\end{array}$ & Failure & $\begin{array}{l}\text { Non- } \\
\text { failure }\end{array}$ & Failure & $\begin{array}{l}\text { Non- } \\
\text { failure }\end{array}$ & Failure & $\begin{array}{l}\text { Non- } \\
\text { failure }\end{array}$ \\
\hline $\begin{array}{l}\text { Men } \\
\text { Women }\end{array}$ & $\begin{array}{l}\ldots \\
\cdots\end{array}$ & $\begin{array}{l}88 \\
74\end{array}$ & $\begin{array}{r}88 \\
120\end{array}$ & $\begin{array}{l}25 \\
24\end{array}$ & $\begin{array}{l}38 \\
42\end{array}$ & $\begin{array}{l}37 \\
18\end{array}$ & $\begin{array}{l}28 \\
32\end{array}$ & $\begin{array}{l}18 \\
26\end{array}$ & $\begin{array}{l}16 \\
38\end{array}$ & $\begin{array}{l}8 \\
6\end{array}$ & $\begin{array}{l}6 \\
8\end{array}$ \\
\hline Total & $\ldots$ & 162 & 208 & 49 & 80 & 55 & 60 & 44 & 54 & 14 & 14 \\
\hline
\end{tabular}

the series as a whole and in each separate age-group. The age and sex distributions of the 370 cases are shown in Table $I$.

The term "cardiac failure" is used in a generally accepted sense to include both acute cardiac deaths, such as cardiac tamponade and acute left ventricular failure, and chronic congestive failure. The criteria for the diagnosis of chronic congestive failure were the presence of the classical clinical findings in life, confirmed by necropsy findings of passive congestion of lungs, liver, spleen, kidneys, and viscera generally. In addition a few patients in whom clinical data were inadequate but who showed the characteristic appearances of passive venous congestion at necropsy were also included.

\section{RESULTS}

Thirteen different abnormalities occurred with sufficient frequency to justify individual attention. Most are well-recognized pathological or clinical entities, described in standard textbooks. These include ischæmic, hypertensive, and rheumatic heart disease, cor pulmonale, syphilis, bacterial endocarditis, and calcified aortic stenosis: their incidence is represented diagrammatically in Fig. 1. In addition, several less well-recognized conditions were encountered, including non-bacterial (thrombotic "malignant") endocarditis, calcification of the mitral valve ring, mucoid degeneration of atrio-ventricular valves, senile cardiac amyloidosis, and post-inflammatory thickening of the valves of indeterminate ætiology. The incidence of these is shown diagrammatically in Fig. 2. Single cases of rheumatoid aortic disease, atheromatous aortic incompetence, rupture of the membranous

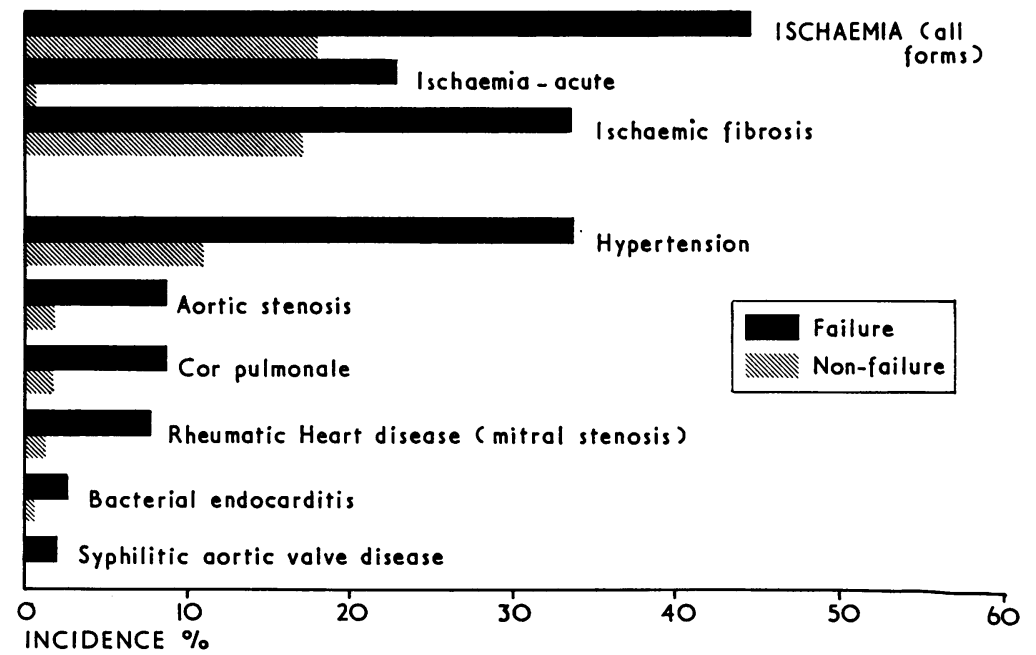

FIG. 1.-Comparative incidence of the well-recognized cardiac abnormalities in failure and nonfailure cases. 


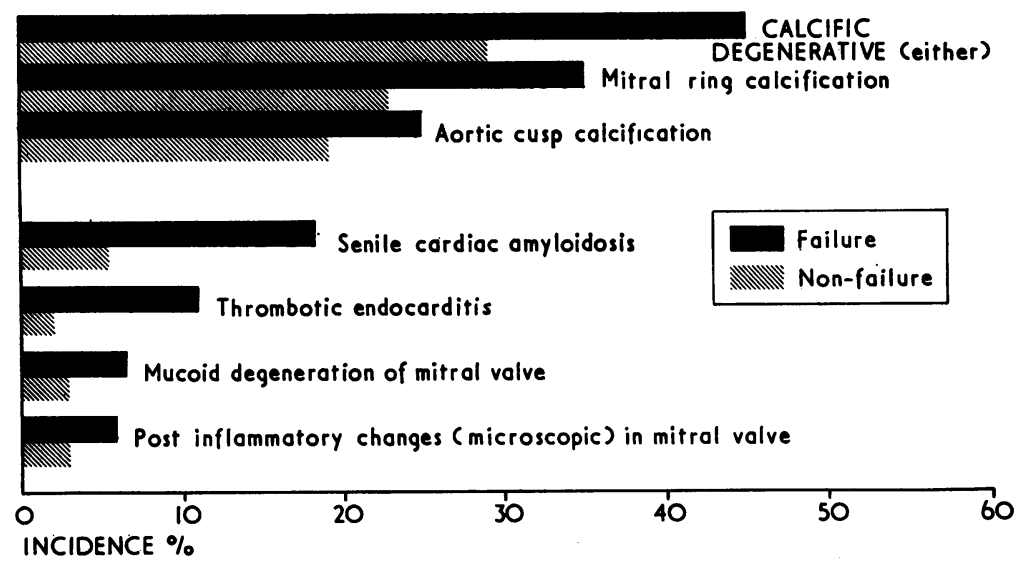

Fig. 2.-Comparative incidence of less well-recognized cardiac abnormalities in failure and nonfailure cases.

interventricular septum, and calcification in a mitral valve varix or hæmatoma were also encountered, and 9 had very minor congenital abnormalities.

Ischamic Heart Disease. As expected, this was the commonest finding in the patients with heart failure ( $48 \%$ ), but was also found in 18 per cent of the non-failure patients. Much of the difference was made up of recent active infarction, which was present in 23 per cent of those with failure, and only found in one $(0.5 \%)$ of the others. As noted by McKeown (1963) demonstrable total coronary occlusion was commoner in these elderly hearts than is generally believed; complete obstruction of a major coronary artery by thrombus or hæmorrhagic atheromatous debris was present in approximately half the cases with recent infarction, the remainder showing apparently uncomplicated atheromatous stenosis. Cardiac rupture had occurred in 5(3\%). Chronic ischæmic changes, in the form of fibrosed infarcts, and focal or diffuse myocardial fibrosis, were only twice as frequent in the failure group $(35 \%)$ as the non-failure group $(17 \%)$, and this difference again was due to cases with localized infarcts. The incidence of patchy diffuse fibrosis, whether grossly visible or only diagnosed on microscopy, was the same in both groups $(13 \%)$.

Variations in the incidence of ischæmic heart disease with age were not great between 75 and 90 years in the failure group, but there was a significant fall in those over 90 . However, as there were only 14 patients over 90 with failure, these results are of doubtful significance. In the non-failure patients the incidence of chronic ischæmic lesions did appear to increase with age (Table II).

TABLE II

COMPaRative INCIDENCE of IsChemic Heart Disease

\begin{tabular}{|c|c|c|c|c|c|c|c|c|c|}
\hline & & & & & \multicolumn{5}{|c|}{ Age-group (yr.) } \\
\hline & & & & & All over 75 & $75-79$ & $80-84$ & $85-89$ & Over 90 \\
\hline $\begin{array}{l}\text { All forms }(\%) \\
\text { Failure } \\
\text { Non-failure }\end{array}$ & $\begin{array}{l}\cdots \\
\cdots\end{array}$ & $\begin{array}{l}\cdots \\
\cdots\end{array}$ & $\begin{array}{l}\cdots \\
\cdots\end{array}$ & $\begin{array}{l}\cdots \\
\cdots\end{array}$ & $\begin{array}{l}48 \cdot 5 \\
18\end{array}$ & $\begin{array}{l}54 \\
17 \cdot 5\end{array}$ & $\begin{array}{c}47 \cdot 5 \\
8\end{array}$ & $\begin{array}{l}49 \\
26\end{array}$ & $\begin{array}{l}28 \cdot 5 \\
28 \cdot 5\end{array}$ \\
\hline $\begin{array}{l}\text { Acute }(\%) \\
\text { Failure } \\
\text { Non-failure }\end{array}$ & $\begin{array}{l}\cdots \\
\cdots\end{array}$ & $\begin{array}{l}\cdots \\
\cdots\end{array}$ & $\begin{array}{l}\cdots \\
\cdots\end{array}$ & $\begin{array}{l}. . \\
.\end{array}$ & $\begin{array}{r}23 \cdot 5 \\
0.5\end{array}$ & $\begin{array}{l}28 \\
1 \cdot 2\end{array}$ & $\begin{array}{r}20 \\
0\end{array}$ & $\begin{array}{r}24 \\
0\end{array}$ & $\begin{array}{r}14 \\
0\end{array}$ \\
\hline $\begin{array}{c}\text { Chronic fibrosis ( } \\
\text { Failure } \\
\text { Non-failure }\end{array}$ & $\begin{array}{l}\ldots \\
\ldots\end{array}$ & 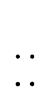 & $\begin{array}{l}\cdots \\
\cdots\end{array}$ & $\begin{array}{l}. \\
\ldots\end{array}$ & $\begin{array}{l}35 \\
17 \cdot 5\end{array}$ & $\begin{array}{l}38 \\
16\end{array}$ & $\begin{array}{r}33 \\
8\end{array}$ & $\begin{array}{l}38 \\
26\end{array}$ & $\begin{array}{l}28 \cdot 5 \\
28 \cdot 5\end{array}$ \\
\hline
\end{tabular}




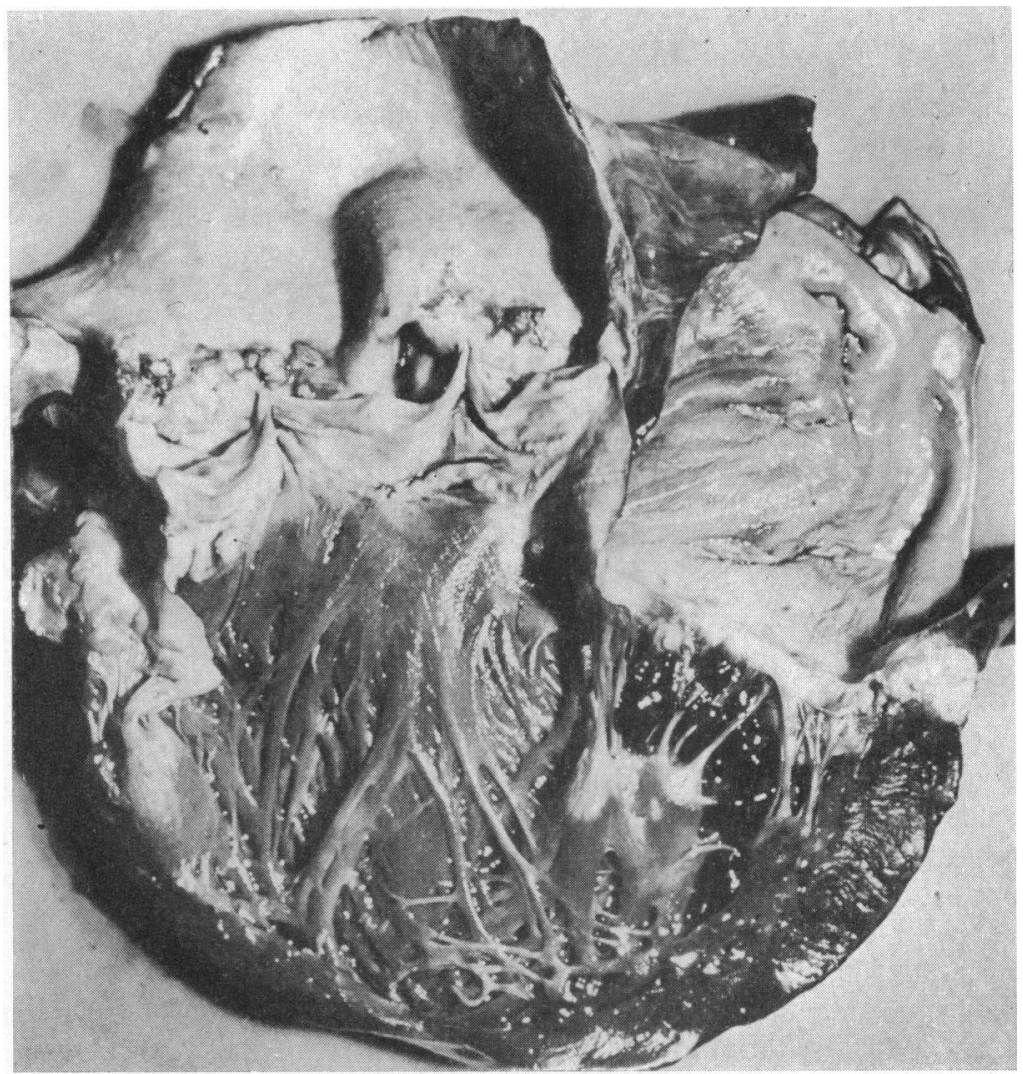

FIG. 3.-Left side of opened heart. There is heavy calcification of the mitral valve ring which extends into the cavity of the left ventricle, displacing the posterior cusp of the valve into the atrium which is dilated.

Calcific Valvular Degenerative Changes. This finding was only slightly less common than ischæmic lesions in the failure group $(45 \%)$, and the commonest finding in the non-failure group. The term is used to describe two forms of calcium deposition which are known to be common in the aged: (a) calcification in the mitral valve ring (Fig. 3), and (b) calcification of the aortic cusp fibrosa. Aortic stenosis and sclerosis resulting from the latter condition are discussed in all reviews of geriatric heart disease, but are not generally distinguished from stenosis due to calcification of fused aortic commissures. In the present series the incidence did not vary significantly with age or cardiac failure. The clinical importance of mitral ring calcification is not yet widely recognized, but there seems no doubt that it can result in mitral incompetence and heart block. It is undoubtedly an ageing phenomenon, seen only in the elderly heart, and, as would be anticipated, the incidence rose with age, while remaining higher in the failure cases, but fell again in the over-90 group (Table III).

Hypertensive Heart Disease. The range of blood pressure in old age shows considerable variation, but $210 / 110 \mathrm{~mm}$. $\mathrm{Hg}$ seems to be the generally accepted upper limit of normal (Caird, 1963). Of the heart failure patients, 35 per cent had readings above this level in their final admission or were known to have been hypertensive from previous admissions, compared with 11 per cent of non-failure patients. Rather surprisingly, since hypertension is generally considered a disease of late middle age, the incidence in both groups rose with age up to 90 years, when it fell to 21 per cent of failure cases, and none in those without failure (Table IV). 
TABLE III

Comparative Incidence of Calcific Valvular Degenerative Changes

\begin{tabular}{|c|c|c|c|c|c|c|c|c|c|}
\hline & & & & & \multicolumn{5}{|c|}{ Age-group (yr.) } \\
\hline & & & & & All over 75 & $75-79$ & $80-84$ & $85-89$ & Over 90 \\
\hline $\begin{array}{c}\text { Either form }(\%) \\
\text { Failure } \quad . \\
\text { Non-failure }\end{array}$ &.. & $\ddot{.}$ & 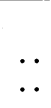 & $\because$. & $\begin{array}{l}45 \\
29\end{array}$ & $\begin{array}{l}34 \\
20\end{array}$ & $\begin{array}{l}38 \\
28 \cdot 5\end{array}$ & $\begin{array}{l}67 \\
39\end{array}$ & $\begin{array}{l}43 \\
50\end{array}$ \\
\hline $\begin{array}{c}\text { Mitral ring calci } \\
\text { Failure } \\
\text { Non-failure }\end{array}$ & $\begin{array}{l}\text { tion } \\
. \\
. .\end{array}$ & $\begin{array}{l}\text { o) } \\
\ldots \\
\ldots\end{array}$ & 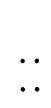 & $\because$ & $\begin{array}{l}35 \\
22 \cdot 5\end{array}$ & $\begin{array}{l}24 \\
15\end{array}$ & $\begin{array}{l}25 \\
21 \cdot 5\end{array}$ & $\begin{array}{l}60 \\
33\end{array}$ & $\begin{array}{l}35 \\
28 \cdot 5\end{array}$ \\
\hline $\begin{array}{l}\text { Aortic cusp calci } \\
\text { Failure } \\
\text { Non-failure }\end{array}$ & $\begin{array}{l}\text { tion } \\
. \\
. .\end{array}$ & $\begin{array}{l}\text { 6) } \\
\ldots \\
\ldots\end{array}$ & $\begin{array}{l}\ldots \\
. .\end{array}$ & .. & $\begin{array}{l}25 \\
18 \cdot 5\end{array}$ & $\begin{array}{l}26 \\
12 \cdot 5\end{array}$ & $\begin{array}{l}16 \cdot 2 \\
18\end{array}$ & $\begin{array}{l}35 \\
22\end{array}$ & $\begin{array}{l}21 \cdot 5 \\
28.5\end{array}$ \\
\hline
\end{tabular}

These three findings were those most often seen in patients over 75 years in this hospital. Each may have been the only cardiovascular abnormality present, but multiple pathology was more often seen. This problem is considered further later in this communication. The remaining less common pathological abnormalities encountered are considered in order of frequency.

Senile Cardiac Amyloidosis. This appears to be a clinically distinct variety of primary amyloidosis (Briggs, 1961) characterized by the advanced age of the patients, and almost entirely cardiac localization of the deposits which surround, compress, and finally replace the myocardial fibres. It was present in 18 per cent of patients with cardiac failure, and 5 per cent of those without. The incidence in both groups rose with age and was as high as 71 per cent of the 14 patients over 90 years with cardiac failure (Table IV).

Endocarditis. Recent fibrin vegetations were found on the mitral or aortic valve in 11 per cent of the failure patients. The non-bacterial (thrombotic) form was commonest (Fig. 4), but bacterial endocarditis (Fig. 5) was present in 3 per cent of those with failure, as well as in one $(0.5 \%)$ apparently not in failure. The mitral valve was most often involved, with vegetations on the line of apposition, or on other areas of endothelial damage such as the commissures in rheumatic mitral stenosis, or over severe mitral ring calcification. Vegetations on the aortic valve alone were present in only 2 $(1 \%)$. None of these had been diagnosed before death and the incidence was not apparently related to age (Table $\mathrm{V}$ ).

TABLE IV

Comparative Incidence of Hypertensive Heart Disease and of Senile Cardiac Amyloidosis

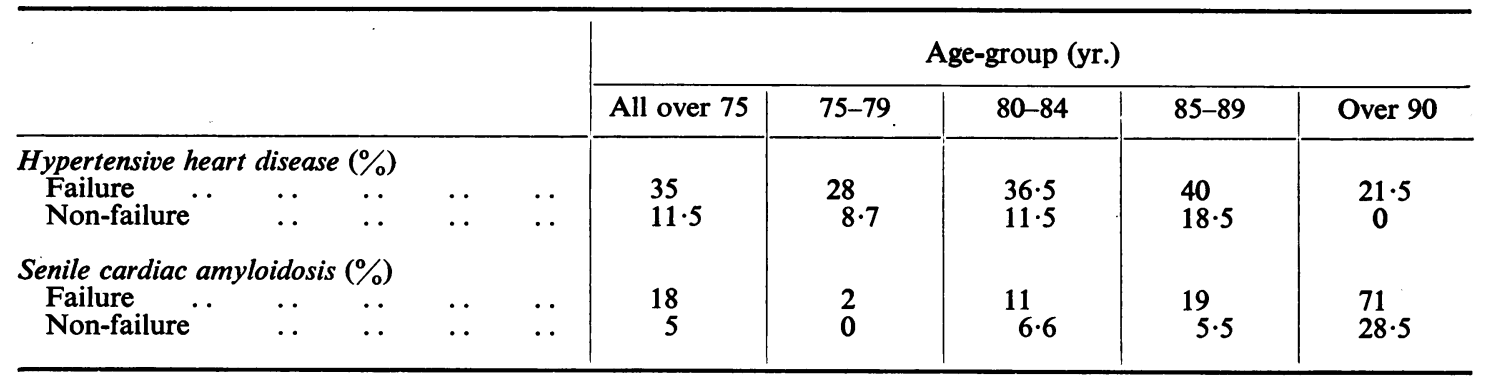




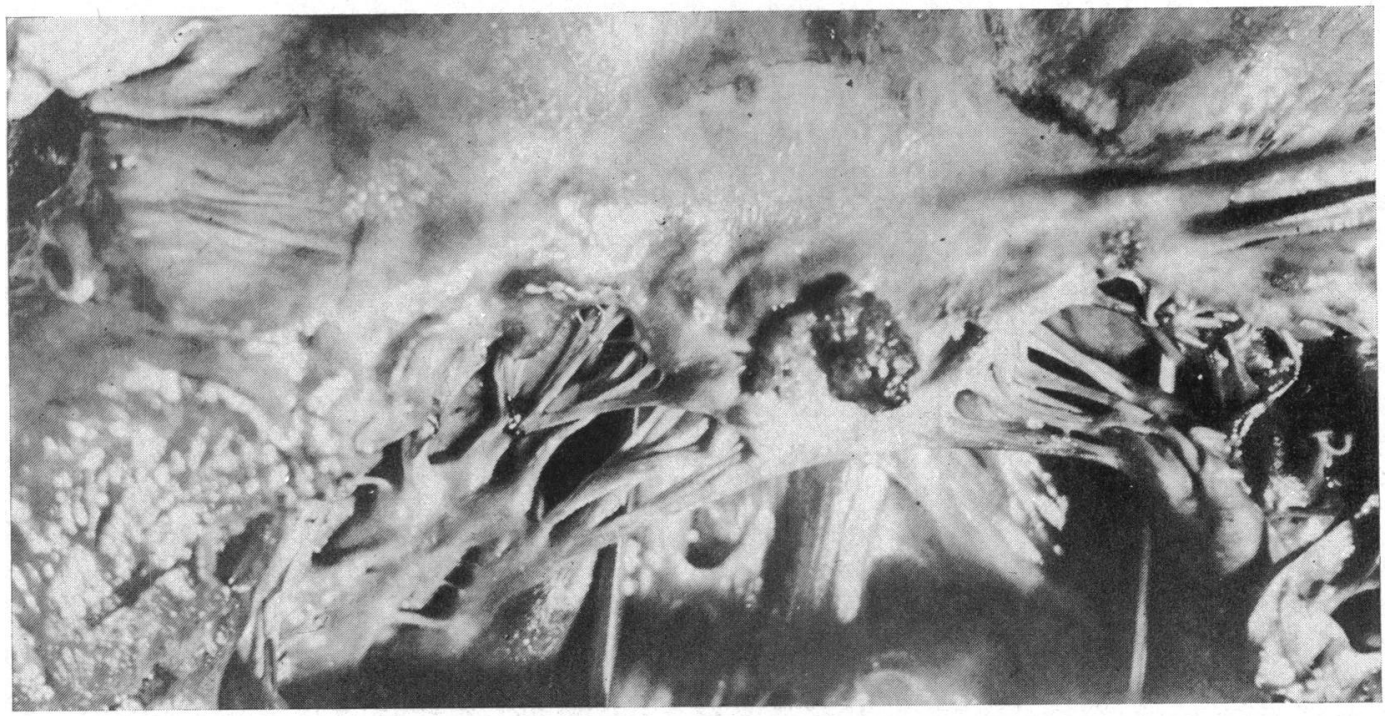

FIG. 4.-Part of a mitral valve with a warty non-bacterial vegetation on the anterior cusp.

Calcified Aortic Stenosis. This term is used to describe the lesions in which the orifice of the valve was reduced by commissural fusion (Fig. 6), in contrast to the degenerative calcification (see above) where deposition of calcium in the cusp fibrosa starts centrally and results in varying degrees of immobilization of the cusps without reducing the anatomical circumference of the valve. Commissural fusion may originate as a congenital abnormality or follow aortic endocarditis.

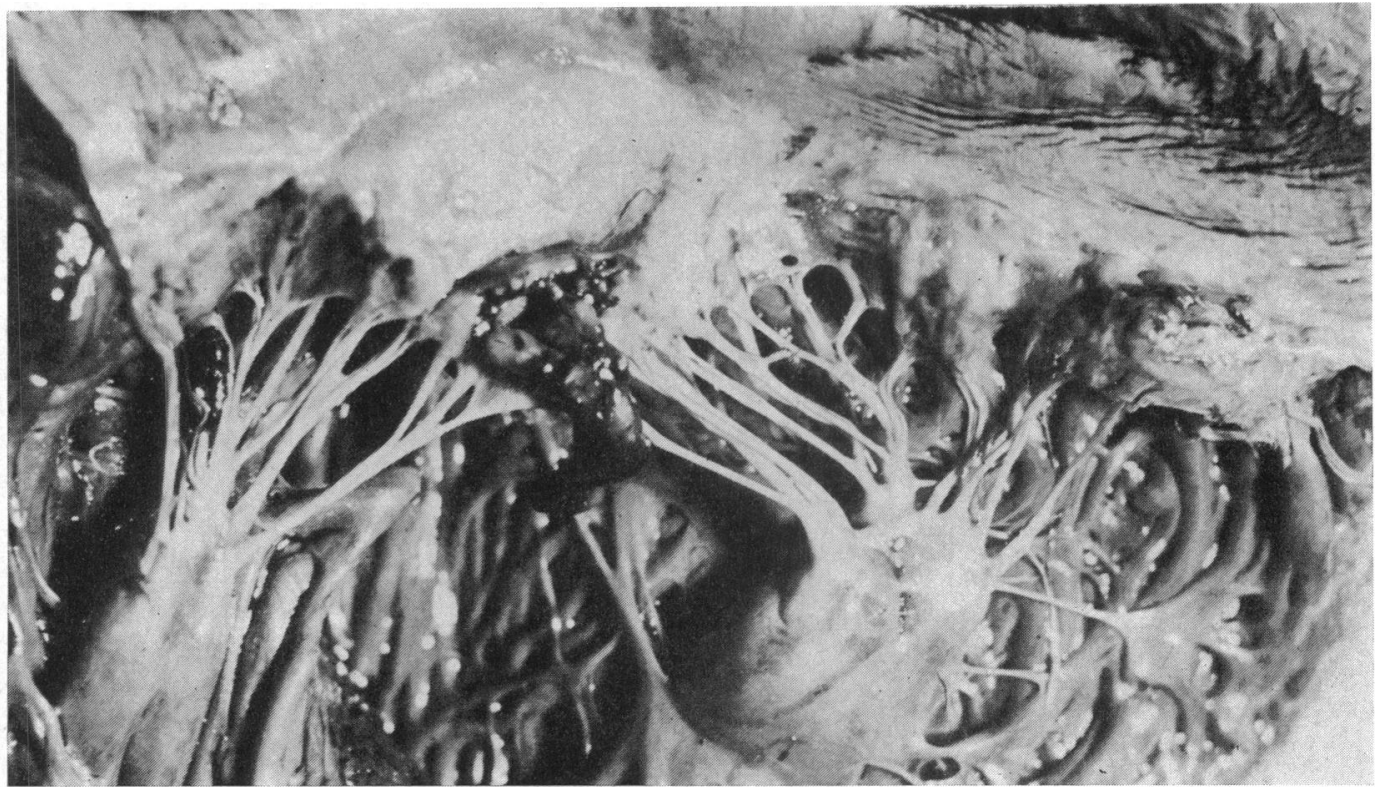

Fig. 5.-Mitral valve with a perforation of the anterior cusp through a pedunculated vegetation (staphylococcal), and an area of endocarditis on the opposing surface of the posterior cusp. 
TABLE V

COMPARATIVE INCIDENCE OF ENDOCARDITIS

\begin{tabular}{|c|c|c|c|c|c|c|c|c|c|}
\hline & & & & & \multicolumn{5}{|c|}{ Age-group (yr.) } \\
\hline & & & & & All over 75 & $75-79$ & $80-84$ & $85-89$ & Over 90 \\
\hline $\begin{array}{c}\text { All forms }(\%) \\
\text { Failure } \\
\text { Non-failure }\end{array}$ & $\begin{array}{l}\cdots \\
.\end{array}$ & $\begin{array}{l}\cdots \\
.\end{array}$ & 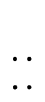 & 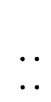 & $\begin{array}{r}11 \\
2\end{array}$ & $\begin{array}{r}10 \\
1\end{array}$ & $\begin{array}{l}9 \\
0\end{array}$ & $\begin{array}{r}13 \cdot 5 \\
5 \cdot 5\end{array}$ & $\begin{array}{r}14 \\
0\end{array}$ \\
\hline $\begin{array}{c}\text { Bacterial }(\%) \\
\text { Failure } \\
\text { Non-failure }\end{array}$ & $\ddot{.}$ & 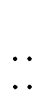 & 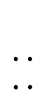 & 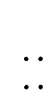 & $\begin{array}{l}3 \\
0.5\end{array}$ & $\begin{array}{l}4 \\
1\end{array}$ & $\begin{array}{l}2 \\
0\end{array}$ & $\begin{array}{l}\mathbf{0} \\
\mathbf{0}\end{array}$ & $\begin{array}{l}7 \\
0\end{array}$ \\
\hline
\end{tabular}

Since the ætiology is no longer determinable once calcification is advanced, no attempt has been made to subdivide those with calcified aortic stenosis on an ætiological basis, and the group, therefore, probably includes patients with congenitally abnormal valves as well as those with rheumatic aortic stenosis. Calcified aortic stenosis was found in 9 per cent of the failure series: there were only $4(2 \%)$ in the non-failure group (Table VI).

Cor Pulmonale. Right ventricular hypertrophy, due to chronic chest disease, was found in 9 per cent of those with congestive failure, and 2 per cent of those without cardiac signs or symptoms. The incidence did not appear to be related to age (Table VI).

Rheumatic Heart Disease. Only patients with the characteristic macroscopic appearances of rheumatic mitral valve disease (i.e. thickening and distortion of cusps, adhesion of commissures and fibrous contraction of chordæ tendineæ) were placed in this category. Isolated aortic stenosis is

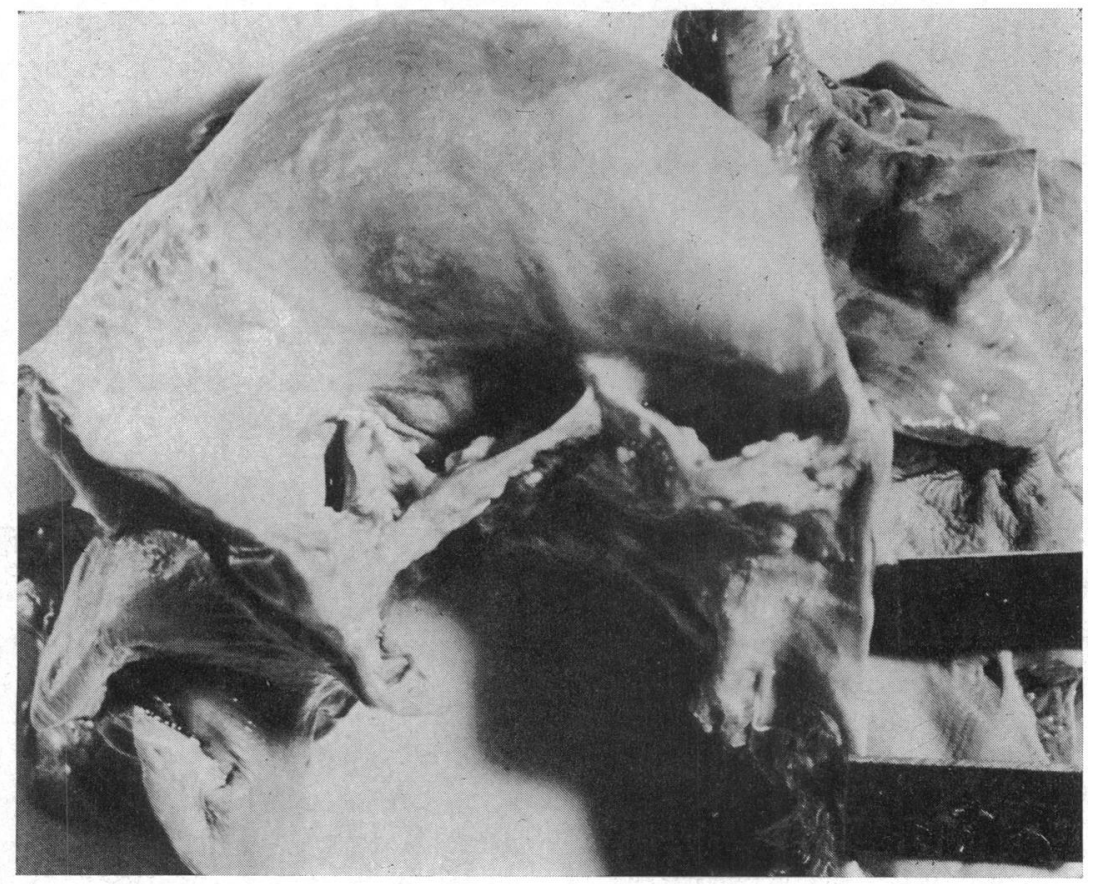

Fig. 6. - Two cusps and part of the third cusp of an aortic valve seen from above. The commissure on the left shows extensive fusion, with heavy calcification superimposed. 
TABLE VI

Comparative Incidence of Calcified Aortic Stenosis, of Cor Pulmonale, and of Rheumatic Heart Disease

\begin{tabular}{|c|c|c|c|c|c|c|c|c|c|}
\hline & & & & & \multicolumn{5}{|c|}{ Age-group (yr.) } \\
\hline & & & & & All over 75 & $75-79$ & $80-84$ & $85-89$ & Over 90 \\
\hline $\begin{array}{l}\text { Calcified aortic s } \\
\text { Failure } \\
\text { Non-failure }\end{array}$ & $\begin{array}{l}\text { osis } \\
\ldots \\
\cdots\end{array}$ & $\begin{array}{l}\cdots \\
\cdots\end{array}$ & $\begin{array}{l}\cdots \\
\cdots\end{array}$ & $\begin{array}{l}\cdots \\
\cdots\end{array}$ & $\begin{array}{l}9 \\
2\end{array}$ & $\begin{array}{l}8 \\
1\end{array}$ & $\begin{array}{l}9 \\
0\end{array}$ & $\begin{array}{r}13 \cdot 5 \\
5 \cdot 5\end{array}$ & $\begin{array}{l}0 \\
0\end{array}$ \\
\hline $\begin{array}{c}\text { Cor pulmonale }( \\
\text { Failure } \\
\text { Non-failure }\end{array}$ & . & $\begin{array}{l}\cdots \\
.\end{array}$ & $\begin{array}{l}\cdots \\
\cdots\end{array}$ & $\begin{array}{l}\ldots \\
\cdots\end{array}$ & $\begin{array}{l}9 \\
2\end{array}$ & $\begin{array}{l}6 \\
0\end{array}$ & $\begin{array}{l}13 \\
3 \cdot 3\end{array}$ & $\begin{array}{l}8 \\
3 \cdot 7\end{array}$ & $\begin{array}{l}7 \\
0\end{array}$ \\
\hline $\begin{array}{c}\text { Rheumatic heart } \\
\text { Failure } \\
\text { Non-failure }\end{array}$ & $\begin{array}{c}\text { ease } \\
\ldots \\
\ldots\end{array}$ & $\begin{array}{l}0^{*} \\
\ldots \\
.\end{array}$ & $\begin{array}{l}\ldots \\
\ldots\end{array}$ & $\begin{array}{l}\ldots \\
\ldots\end{array}$ & $\begin{array}{l}8 \\
1 \cdot 5\end{array}$ & $\begin{array}{l}10 \\
3 \cdot 7\end{array}$ & $\begin{array}{l}5 \cdot 5 \\
0\end{array}$ & $\begin{array}{l}8 \\
0\end{array}$ & $\begin{array}{l}7 \\
0\end{array}$ \\
\hline
\end{tabular}

* Excluding isolated aortic stenosis.

considered separately, as are patients with microscopical changes only. Rheumatic heart disease was present in 8 per cent of the failure group and 1.5 per cent of the non-failure group. The incidence did not change appreciably with age in the failure group, but no patients over 80 years of age were present in the non-failure group (Table VI).

Microscopical Post-inflammatory Changes. It was not uncommon to see mitral valves without the characteristic gross pathology of rheumatic heart disease but where the valve was uniformly white,

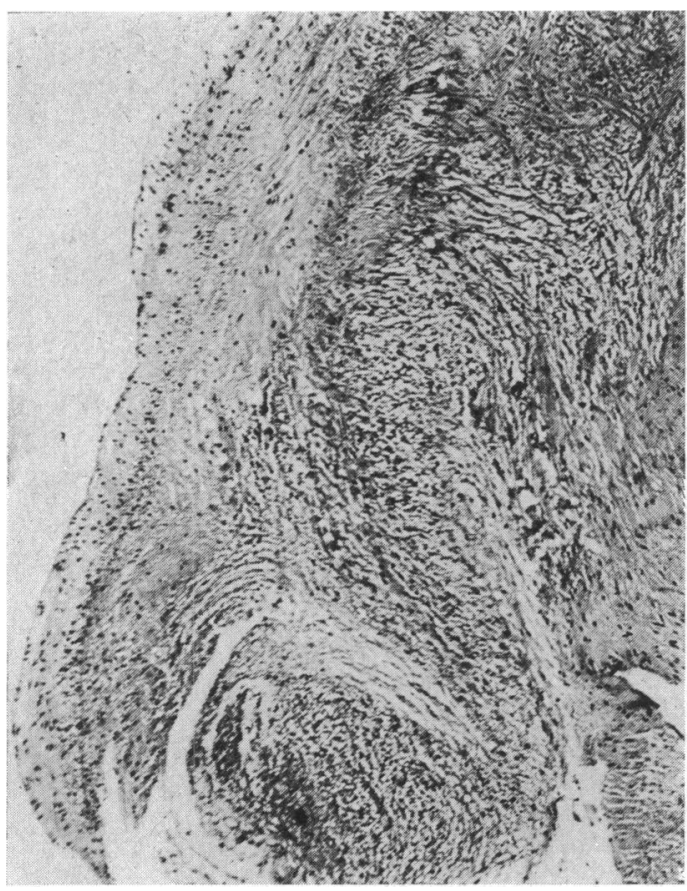

Fig. 7.-Photomicrograph of part of a mitral valve showing replacement of the normally dense collagenous structure of the fibrosa by loose "myxomatous" tissue. (Hæmatoxylin and eosin. $\times 66$.) opaque, and possibly very slightly thickened. Microscopically, many of these showed abnormal vascularization of the valve spongiosa, and disorganization of the normal layers of the cusp. The appearances indicated previous inflammation, but Aschoff bodies were never seen, and they are therefore classified as non-specific. Six per cent of those with failure, and 3 per cent of those without failure showed these changes, and the incidence in the failure group rose slightly with age (Table VII).

Mucoid Degeneration of Atrio-ventricular Valves. This is a curious degenerative process of unknown ætiology, in which the normally dense collagenous valve fibrosa undergoes transformation into a loose metachromatically staining substance (Fig. 7). The process appears to start in the distal half of the cusp, and results in ballooning of the valve leaflet, which thus resembles a parachute (Fig. 8); the valve may prolapse into the atrium in systole, becoming incompetent. The chordæ tendineæ become thinned, and can rupture spontaneously. Of the failure group, 6 per cent showed a grossly recognizable degree of this process, as did 3 per cent of non-failure cases. The incidence also rose with age between 75 and 89 years in both groups, but there were no cases over 90 years (Table VII). 


\section{TABLE VII}

Comparative Incidence of Microscopical Post-Inflammatory Changes (Mitral Valve) and Mucoid Degeneration OF THE MITRAL VALVE

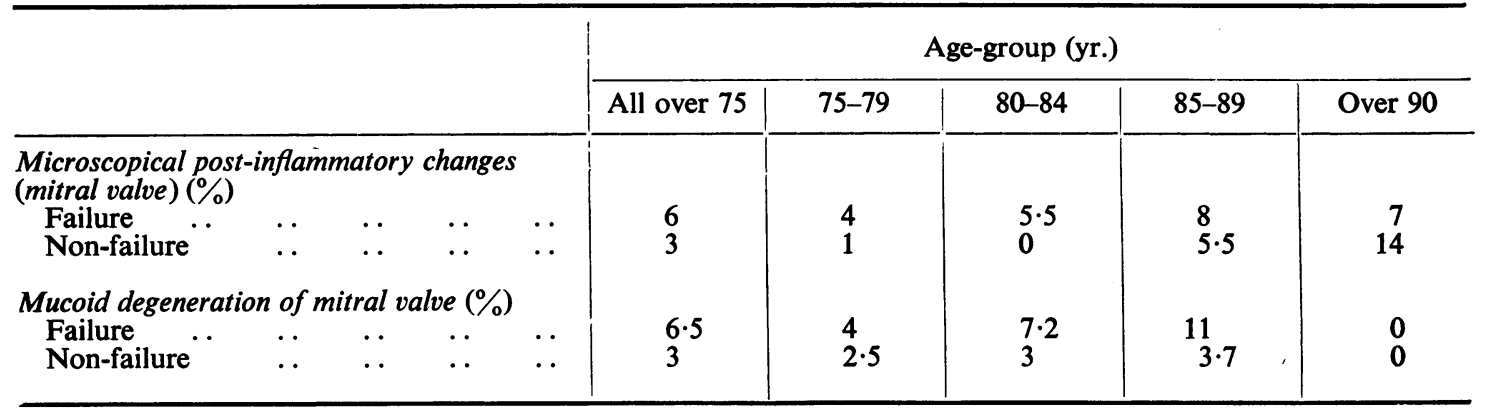

Syphilitic Aortitis. Aortic incompetence was uncommon. There were only three cases (2\%), all in the failure group, with syphilitic aortic incompetence.

Frequency in Hearts with only one Pathological Abnormality. The difficulty of determining the cause of cardiac failure in an elderly patient in life is frequently reflected in the difficulty of determining which of two or more pathological abnormalities found at necropsy was responsible for precipitating failure. No problem occurs with large recent infarcts, or cardiac rupture, but in a patient with hypertensive heart disease and diffuse ischæmic myocardial fibrosis for example it is not possible to determine which of these was the more important in causing the terminal left ventricular failure. In patients with several minor abnormalities, speculation as to which, if any, of these was responsible for failure may be even more unrewarding.

In an attempt to assess the relative importance of the pathological findings described above, the results in hearts with one abnormal finding only were also considered separately (Table VIII).

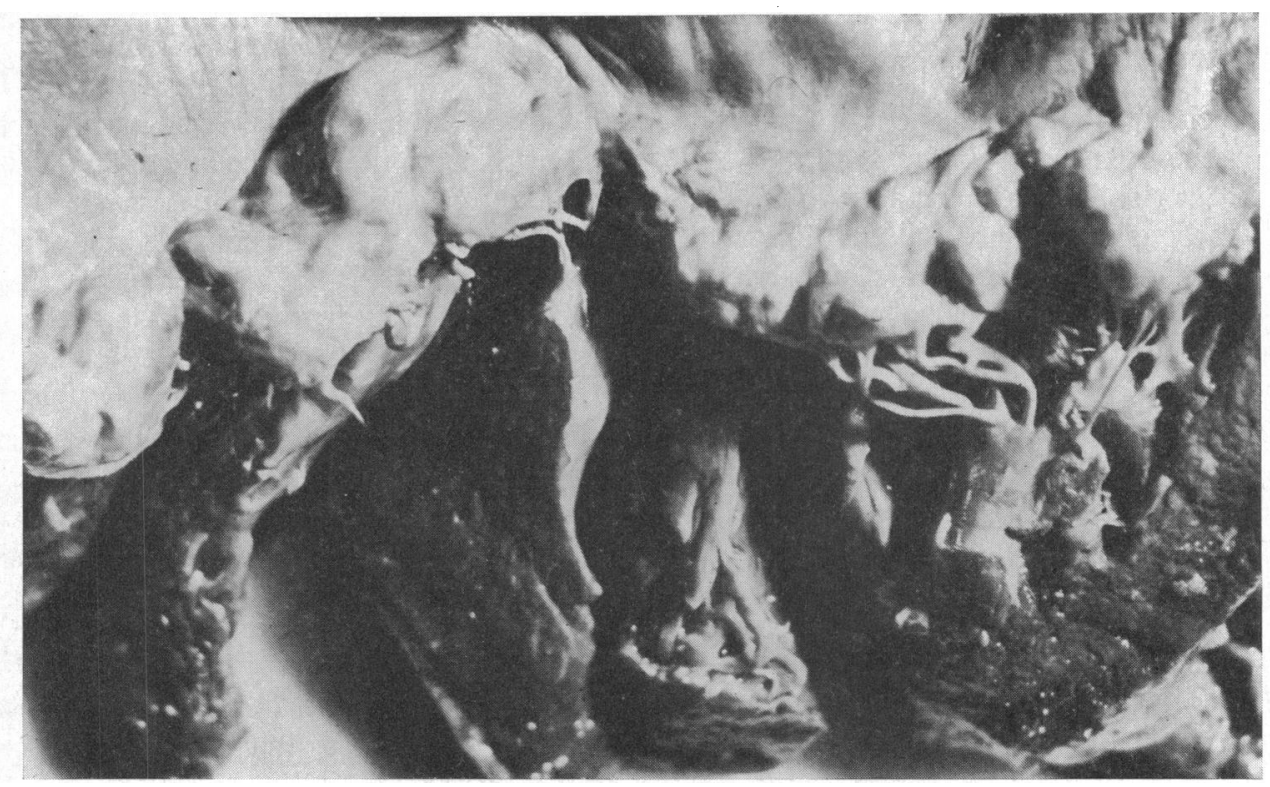

Fig. 8.-Mitral valve showing severe mucoid degeneration. The cusps are voluminous and "parachute" like, and the redundant tissue is particularly well marked in the posterior cusp. 
TABLE VIII

Percentage Incidence of Pathological Abnormalities as Sole Findings

\begin{tabular}{|c|c|c|c|c|c|c|c|c|c|c|}
\hline \multirow[t]{2}{*}{ Pathology } & \multicolumn{2}{|c|}{ Whole group } & \multicolumn{2}{|c|}{$75-79$ years } & \multicolumn{2}{|c|}{$80-84$ years } & \multicolumn{2}{|c|}{$85-89$ years } & \multicolumn{2}{|c|}{ Over 90 years } \\
\hline & Failure & $\begin{array}{c}\text { Non- } \\
\text { failure }\end{array}$ & Failure & $\begin{array}{l}\text { Non- } \\
\text { failure }\end{array}$ & Failure & $\begin{array}{l}\text { Non- } \\
\text { failure }\end{array}$ & Failure & $\begin{array}{l}\text { Non- } \\
\text { failure }\end{array}$ & Failure & $\begin{array}{l}\text { Non- } \\
\text { failure }\end{array}$ \\
\hline $\begin{array}{l}\text { Total ischæmia } \\
\text { (all forms) ... } \\
\text { Ischæmia-acute } \\
\text { Ischæmia- }\end{array}$ & $\begin{array}{r}13 \\
9\end{array}$ & $\begin{array}{r}11 \cdot 5 \\
0.5\end{array}$ & $\begin{array}{l}16 \\
12\end{array}$ & $\begin{array}{c}15 \\
1 \cdot 2\end{array}$ & $\begin{array}{l}14 \cdot 5 \\
11\end{array}$ & $\begin{array}{l}7 \\
0\end{array}$ & $\begin{array}{l}9 \\
4 \cdot 5\end{array}$ & $\begin{array}{r}15 \\
0\end{array}$ & $\begin{array}{r}14 \\
0\end{array}$ & $\begin{array}{l}\mathbf{0} \\
\mathbf{0}\end{array}$ \\
\hline \begin{tabular}{ll}
\multicolumn{1}{c}{ chronic } & $\ldots$ \\
Hypertension & $\ldots$ \\
Cor pulmonale & $\ldots$
\end{tabular} & $\begin{array}{l}2 \cdot 5 \\
1 \cdot 2\end{array}$ & $\begin{array}{r}11 \\
4 \\
1\end{array}$ & $\begin{array}{l}4 \\
0 \\
4\end{array}$ & $\begin{array}{c}14 \\
2 \cdot 5 \\
0\end{array}$ & $\begin{array}{l}3 \cdot 6 \\
7 \cdot 2 \\
0\end{array}$ & $\begin{array}{l}7 \\
7 \\
3 \cdot 5\end{array}$ & $\begin{array}{l}2 \cdot 2 \\
4 \cdot 5 \\
0\end{array}$ & $\begin{array}{r}15 \\
4 \\
0\end{array}$ & $\begin{array}{l}\mathbf{0} \\
\mathbf{0} \\
\mathbf{0}\end{array}$ & $\begin{array}{l}0 \\
0 \\
0\end{array}$ \\
\hline $\begin{array}{c}\text { Rheumatic heart } \\
\text { disease... }\end{array}$ & 2 & $1 \cdot 5$ & 4 & $3 \cdot 7$ & 0 & 0 & $2 \cdot 2$ & 0 & 0 & 0 \\
\hline $\begin{array}{l}\text { Syphilitic heart } \\
\text { disease.: }\end{array}$ & 0 & 0 & 0 & 0 & 0 & 0 & 0 & 0 & 0 & 0 \\
\hline $\begin{array}{l}\text { Endocarditis-all } \\
\text { Endocarditis- }\end{array}$ & 0 & 1 & 0 & $1 \cdot 2$ & 0 & 0 & 0 & 2 & 0 & 0 \\
\hline $\begin{array}{l}\text { bacterial } \\
\text { Post-inflammatory }\end{array}$ & 0 & 0.5 & 0 & $1 \cdot 2$ & 0 & 0 & 0 & 0 & 0 & 0 \\
\hline $\begin{array}{l}\text { Post-inflammatory } \\
\text { changes } \quad . \\
\text { Total degenerative }\end{array}$ & 0 & 1.5 & 0 & $2 \cdot 5$ & 0 & 0 & 0 & 2 & 0 & $\mathbf{0}$ \\
\hline $\begin{array}{l}\text { calcitication } \\
\text { (either form) }\end{array}$ & 3 & 16 & 4 & $17 \cdot 5$ & $3 \cdot 6$ & $21 \cdot 5$ & 7 & 7 & 0 & 20 \\
\hline $\begin{array}{l}\text { Mitral ring } \\
\text { calcification } \\
\text { Aortic cusp }\end{array}$ & 3 & 7 & 4 & $6 \cdot 2$ & 2 & 7 & $4 \cdot 5$ & 5 & 0 & 14 \\
\hline $\begin{array}{l}\text { Aortic cusp } \\
\text { calcification . . }\end{array}$ & 0.6 & 4 & 0 & 5 & 0 & 5 & $2 \cdot 2$ & 2 & 0 & 0 \\
\hline $\begin{array}{l}\text { Calcified aortic } \\
\text { stenosis } \\
\text { Senile cardiac }\end{array}$.. & $1 \cdot 2$ & $0 \cdot 5$ & 4 & $1 \cdot 2$ & 0 & 0 & 0 & $\mathbf{0}$ & 0 & 0 \\
\hline $\begin{array}{l}\text { Senile cardiac } \\
\text { amyloidosis }\end{array}$ & $2 \cdot 5$ & $3 \cdot 5$ & 2 & 0 & 0 & 7 & $2 \cdot 2$ & 2 & 14 & 14 \\
\hline $\begin{array}{l}\text { Mucold } \\
\text { degeneration .. }\end{array}$ & 0 & 1 & 0 & $1 \cdot 2$ & 0 & 0 & 0 & 2 & 0 & 0 \\
\hline
\end{tabular}

Ischæmic changes remained the most common finding in the failure group $(13 \%)$, and degenerative heart disease in the non-failure group $(16 \%)$. Not surprisingly, acute ischæmic changes were the most frequent solitary abnormality found in the heart failure cases, and occurred more than twice as frequently as any other single pathological process. Chronic ischæmic changes alone, however, were far commoner in the non-failure series $(11 \%$ compared with $2.5 \%)$. There was no difference in the incidence of hypertensive heart disease in failure and non-failure groups $(4 \%)$, and the number of hearts in which only one of the other findings under consideration was seen were too few for the figures to have any comparative value. Syphilitic aortitis and endocarditis were not seen as isolated findings.

Multiple Pathology. It is clear from the previous paragraph that cases of cardiac failure showing only one pathological abnormality are the minority, and are mainly those with recent myocardial infarction. When the number of separate abnormalities seen in each heart was determined, and the figures compared as previously (Table IX) multiple pathology was far commoner in the failure cases, with 65 per cent showing two or more of the pathological processes just described, compared with 13 per cent of the non-failure group. Since multiplicity of diseases generally increases with age, the finding that the number of cardiac abnormalities also increases with age is to be anticipated. This rise was more marked in the failure group. Patients with more than two findings were uncommon in the non-failure group, though these findings include ones often stated to be normal in old age. The large number of patients showing no pathological abnormality in spite of advanced age is of interest. This number naturally decreased with age, but over one-quarter of the 85-89 
TABLE IX

InCidence of Multiple Pathology

\begin{tabular}{|c|c|c|c|c|c|c|c|c|c|c|}
\hline \multirow{2}{*}{$\begin{array}{l}\text { No. of pathological } \\
\text { abnormalities per } \\
\text { heart }\end{array}$} & \multicolumn{2}{|c|}{ Whole group } & \multicolumn{2}{|c|}{$75-79$ years } & \multicolumn{2}{|c|}{$80-84$ years } & \multicolumn{2}{|c|}{$85-89$ years } & \multicolumn{2}{|c|}{ Over 90 years } \\
\hline & Failure & $\begin{array}{c}\text { Non- } \\
\text { failure }\end{array}$ & Failure & $\begin{array}{c}\text { Non- } \\
\text { failure }\end{array}$ & Failure & $\begin{array}{l}\text { Non- } \\
\text { failure }\end{array}$ & Failure & $\begin{array}{l}\text { Non- } \\
\text { failure }\end{array}$ & Failure & $\begin{array}{l}\text { Non- } \\
\text { failure }\end{array}$ \\
\hline $\begin{array}{l}0 \\
1 \\
2 \\
3 \\
4 \\
5\end{array}$ & $\begin{array}{l}4 \cdot 5^{*} \\
30 \\
44 \\
15 \\
5 \\
1\end{array}$ & $\begin{array}{l}39 \\
47 \cdot 5 \\
11 \\
2 \cdot 5 \\
0 \\
0\end{array}$ & $\begin{array}{l}2^{*} \\
39 \\
49 \\
8 \\
2 \\
0\end{array}$ & $\begin{array}{r}46 \\
49 \\
4 \\
1 \\
0 \\
0\end{array}$ & $\begin{array}{c}5 \cdot 5^{*} \\
49 \cdot 5 \\
44 \cdot 5 \\
16 \\
4 \cdot 5 \\
0\end{array}$ & $\begin{array}{r}45 \\
47 \\
8 \\
0 \\
0 \\
0\end{array}$ & $\begin{array}{c}7^{7 *} \\
28 \\
43 \\
11 \\
9 \\
2\end{array}$ & $\begin{array}{l}26 \cdot 5 \\
48 \\
18 \\
7 \cdot 5 \\
0 \\
0\end{array}$ & $\begin{array}{c}0 \\
21 \cdot 5 \\
28 \cdot 5 \\
34 \\
7 \\
0\end{array}$ & $\begin{array}{c}28 \cdot 5 \\
35 \\
35 \\
0 \\
0 \\
0\end{array}$ \\
\hline
\end{tabular}

* Severe anæmia in 4 cases $(2 \%)$.

and over-90 groups had hearts that were indistinguishable from those of patients up to 40 years younger dying of similar conditions.

"Senile Heart Failure" and Heart Weight. "Senile heart failure" is used as a purely descriptive term by Rose and Wilson (1959) to classify cases of congestive failure with completely normal hearts. This finding was uncommon in the present series. There were only 7 cases, and anæmia probably accounted for the failure in 3 , leaving 2 per cent which fell into the category of "senile heart failure".

Brown atrophy is sometimes thought to be responsible for failure in the elderly, but experience with large numbers of elderly hearts in this hospital has confirmed the findings of Rose and Wilson (1959) that brown atrophy is rather commoner in hearts from patients without cardiac failure. It is generally noted only in small hearts such as those from patients dying of carcinomatosis or other wasting disease, and the small heart is less likely to go into congestive failure (Sonnek, 1954). In the present series no attempt was made to estimate the incidence of brown atrophy, but the heart weights in the two groups were compared. The results agree with those of Sonnek (1954). The average heart weight in the failure group was $440 \mathrm{~g}$. and that in the non-failure group $330 \mathrm{~g}$.

\section{Discussion}

The ætiology of heart failure is often obscure in the elderly, and suggested diagnoses are frequently erroneous or incomplete (Howell, 1963). "Myocardial degeneration" appears as the commonest cause in patients over 75 (General Register Office, 1964). Although implying specific involutional changes, this term has no known pathological basis. Ischæmia is widely held to be the cause of most cases of clinically obscure cardiac failure (Caird, 1963; Agate, 1960; Bedford and Caird, 1956; Boas, 1950), but Rose and Wilson (1959) only found ischæmic changes in 38 per cent of such cases, and similar changes were present in 22 per cent of controls. Diffuse fibrosis was equally frequent in both groups in the present series, confirming Rose and Wilson's (1959) view that the role of ischæmia is overemphasized, and suggesting that Caird's (1963) more recent concept of ischæmia as a contributory factor with other pre-existing pathology is more probable.

In contrast to Rose and Wilson's 36 per cent of patients, only 2 per cent of our failure group had no cardiac abnormality. The present author's results are based on the view that the normal heart in old age is pathologically indistinguishable from the normal heart of any younger adult (Gavey, 1949; Agate, 1960; Steinbach, 1964), and this view was justified by the high proportion of cases in the nonfailure group with hearts indistinguishable from those of patients many years younger. The wellrecognized pathogenic factors in cardiac failure (Fig. 1) are fully discussed in clinical reviews (Caird, 1963; Bedford and Caird, 1956, 1960; Agate, 1960), and the present findings do not differ appreciably from these. However, physicians are becoming increasingly aware that geriatric heart 
disease may be caused by less well-recognized processes (Lancet, 1963). Mitral ring calcification, mucoid degeneration of mitral valves, non-bacterial endocarditis, and microscopical post-inflammatory changes, though not considered in the above surveys, occurred sufficiently often for assessment of incidence in the present series, and all were one and a half to five times commoner in failure than in non-failure cases, suggesting a relationship to the failure. This relationship might be of cause or effect, but only non-bacterial (thrombotic) endocarditis is likely to be a result rather than a cause of failure. This is generally a terminal occurrence, without practical significance, but emboli are not infrequent, and coronary embolism with myocardial infarction from this source is occasionally seen in this hospital. It seems likely that the remaining abnormalities found are factors in the pathogenesis of congestive failure in the aged.

Calcification of the mitral valve ring and aortic cusp fibrosa are described as common in ageing (McMillan and Lev, 1964; Gross and Kugel, 1931) and tend to be dismissed as unimportant. It would be surprising, however, if a condition which, when fully developed, prevents contraction of the mitral valve ring and displaces the posterior cusp into the atrium did not have any clinical significance. Communications on functional aspects of ring calcification include mitral incompetence and heart block as results (Rytand and Lipsitch, 1946; Grayson, 1948; Simon and Liu, 1954), and 12 of a recent series of 14 severely affected patients died of cardiac failure attributed to ring calcification (Korn, DeSanctis, and Sell, 1962). In the present series left atrial dilatation, apical systolic murmurs, and conduction defects were also commonly associated with mitral ring calcification. The significance of minor degrees of this condition is not so clear. The junction of mitral ring and membranous interventricular septum is involved early, and therefore ring calcification may be responsible for some cases of heart block which is common in varying degrees in the elderly (Agate, 1960). This type of calcification was indeed found in 6 of Lumb and Shacklett's (1960) 11 patients over 75 years with conduction defects.

Evaluation of the functional significance of well-marked degenerative aortic valve calcification from published work is difficult, since it cannot be distinguished clinically from other causes of aortic valve calcification, and both clinical and pathological surveys tend to consider all types collectively. In the present investigation, the degenerative form is considered separately from commissural calcification, and results justify the generally held view (presumably based on the frequency of minor degrees of aortic cusp calcification) that it is usually of no clinical significance except in producing basal systolic murmurs. The difference in incidence between failure and non-failure patients was small $(25 \%$ compared with $18 \%$ ) much less than for any other condition under consideration, and in only one patient was the calcification heavy enough to immobilize the cusps and significantly impair left ventricular outflow.

References to mucoid degeneration of atrio-ventricular valves are scarce. Fernex and Fernex (1958) describe this condition, with two cases of mitral incompetence caused by it, and Caird's (1963) case of mitral incompetence attributed to "an accessory mitral cusp with stretching of the chordæ and prolapse of the valve in systole" appears to be another example, as the voluminous "parachute" like posterior cusp resembles accessory valve tissue (Fig. 8). The ætiology is unknown, though a similar condition in cattle suggested chronic hypoxia as a factor (Fernex and Fernex, 1958). It was not seen as an isolated finding in our cardiac failure group, but the incidence was twice as high as in the non-failure group. It is, therefore, unlikely to be a direct primary cause of failure though it may well be a contributory factor.

Opinions on the clinical importance of senile cardiac amyloidosis vary, but most agree that it can cause cardiac failure and is likely to do so in a high proportion of severely affected patients (Buerger and Braunstein, 1960; Symmers, 1956; Josselson, Pruitt, and Edwards, 1952). In a series from this hospital (Pomerance, 1965) it appeared responsible for failure in 25 per cent of patients; this proportion is maintained in patients seen since. In the present investigation senile cardiac amyloid was present in 18 per cent of the failure series and in 5 per cent of the non-failure series.

Minor post-inflammatory changes in the mitral valve are not of direct clinical significance, but since they occurred twice as frequently in failure as in non-failure patients and the incidence in- 
creased with age, they may be an indication of previous carditis occurring during the respiratory infections to which the elderly are prone.

Recent clinical reviews are recognizing the importance of multiple pathology in geriatric cardiology (Caird, 1963; Agate, 1960), and the present survey confirms this. Multiple pathology was present in the hearts of 65 per cent of failure patients, compared with 13 per cent of non-failure ones. As anticipated, the incidence rose with age. It was usually difficult to allocate responsibility for the failure to a single pathological factor; the majority of those in whom the cause of failure was unquestionable were patients with recent myocardial infarction. This difficulty parallels clinical experience in determining the pathogenesis of cardiac failure in geriatric patients. It seems probable that in these patients it is the result of two or more relatively minor pathological conditions, of which ischæmic changes are the commonest, and while each may be of no significance alone, when combined with other equally insignificant processes, the aggregated impairment of cardiac efficiency is sufficient to precipitate failure. However, Agate's (1960) statement that congestive failure in the elderly differs from that in younger age-groups only in multiplicity of pathology does not appear justified by the present results, since two of the pathological processes concerned, i.e. senile cardiac amyloidosis and degenerative calcific changes, are only found in elderly patients. The problem of "senile myocardial degeneration" also remains, since there were a few patients with cardiac failure in whom no abnormality could be seen. However, this state of affairs is not unknown in younger age-groups, and merely reflects the limitations of present diagnostic techniques. It remains possible, however, that a specific involutional change may eventually be identified in the myocardium and a further pathological process added to those which can contribute to the pathogenesis of heart failure in old age.

\section{SUMMARY}

The pathological findings in the hearts of 162 patients with cardiac failure who died over the age of 75 have been studied and compared with those in 208 patients in the same age range with clinically normal cardiovascular systems.

In the failure cases, ischæmic heart disease was the commonest finding (48.5\%), followed in order of frequency by degenerative calcific changes in mitral ring or aortic cusp, hypertension, senile cardiac amyloidosis, endocarditis, cor pulmonale, calcified aortic stenosis, rheumatic heart disease, mucoid degeneration of the mitral valve, and syphilis. All these were less common in the non-failure group, where degenerative calcific changes were the most frequent finding $(29 \%)$ followed by ischæmic changes, hypertension, senile cardiac amyloidosis, rheumatic heart disease, cor pulmonale, endocarditis, calcified aortic stenosis, and mucoid degeneration.

The incidence of ischæmia and cor pulmonale did not vary greatly with age in the failure group, neither did rheumatic heart disease, but there were no cases of this disease without failure over the age of 80 . The incidence of the remaining conditions rose by varying degrees with age, though hypertension and calcific degenerative heart disease fell again in patients over 90 with failure, and mucoid degeneration was less frequent in both groups over this age.

The most striking feature of cardiac failure in the elderly was the multiplicity of pathological findings in individual hearts. This increased with age and made assessment of the pathological basis of the failure difficult. Failure of a structurally normal heart ("senile heart failure") was an uncommon finding $(2 \cdot 5 \%)$.

The pathology of the geriatric heart can include any form of adult heart disease, and, in addition, senile cardiac amyloidosis and degenerative calcific changes in mitral ring and aortic cusp fibrosa, which are found only in the elderly. Failure is usually associated with the presence of two or more pathological processes. These may not appear sufficient to impede cardiac function individually and it is suggested that in these cases the effects of each process are cumulative with eventual failure of the elderly myocardium. 
Thanks are due to the physicians and surgeons of the Central Middlesex Hospital, under whose care these patients were admitted, to Dr. R. A. B. Drury for his continued support and provision of laboratory facilities, and the staff of the Histopathology Department for the technical work involved, and to Mr. F. Warren and Mr. A. Booker for the photography.

I am indebted to the North West Metropolitan Regional Hospital Board Clinical Research Fund for financial support.

\section{REFERENCES}

Agate, J. (1960). Problems of heart disease in the elderly. Brit. J. clin. Pract., 14, 373.

Bedford, P. D., and Caird, F. I. (1956). Congestive heart failure in the elderly. Quart. J. Med., $25,407$.

- and - (1960). Valvular Disease of the Heart in Old Age. J. A. Churchill, London.

Boas, E. P. (1950). Cardiovascular problems after age 70. Geriatrics, 5, 85.

Briggs, G. W. (1961). Amyloidosis. Ann. intern. Med., 55, 943.

Buerger, L., and Braunstein, H. (1960). Senile cardiac amyloidosis. Amer. J. Med., 28, 357.

Caird, F. I. (1963). Heart disease in old age. Postgrad. med. J., 39, 408.

Fernex, M., and Fernex, C. (1958). La dégénérescence mucoïde des valvules mitrales. Ses répercussions fonctionelles. Helv. med. Acta, $25,694$.

Grayson, C. E. (1948). Cardiac calcifications, annular and valvular. Calif. Med., 68, 121.

Gavey, C. J. (1949). The cardiology of old age. Lancet, 2, 725.

General Register Office (1964). Registrar General's Statistical Review of England and Wales for the year 1962. H.M. Stationery Office, London.

Gross, L., and Kugel, M. A. (1931). Topographic anatomy and histology of the valves in the human heart. Amer.J. Path., 7, 445.

Howell, T. H. (1963). Causes of death in nonagenarians. Geront. clin. (Basel), 5, 139.

Josselson, A. J., Pruitt, R. D., and Edwards, J. E. (1952). Amyloid localized to the heart. Analysis of 29 cases. Arch. Path., 54, 359.

Korn, D., DeSanctis, R. W., and Sell, S. (1962). Massive calcification of the mitral annulus. A clinico pathological study of fourteen cases. New Engl. J. Med., 267, 900.

Lancet (1963). Myocardial disorders in the elderly. 2, 672.

Lumb, G., and Shacklett, R. S. (1960). Human cardiac conduction tissue lesions. Amer. J. Path., 36, 411.

McKeown, F. (1963). Heart disease in old age. J. clin. Path., 16, 532.

McMillan, J., and Lev, M. (1964). The ageing heart II-The valves. J. Geront., 19, 1.

Pomerance, A. (1965). Senile cardiac amyloidosis. Brit. Heart J., 27, 711.

Rose, G. A., and Wilson, R. R. (1959). Unexplained heart failure in the aged. Brit. Heart J., $21,511$.

Rytand, D. A., and Lipsitch, L. S. (1946). Clinical aspects of calcification of the mitral annulus fibrosus. Arch. intern. Med., 78, 544.

Simon, M. A., and Liu, S. F. (1954). Calcification of the mitral valve annulus and its relation to functional valvular disturbance. Amer. Heart J., 48, 497.

Sonnek, P. J. (1954). Congestive heart failure in the elderly. Geriatrics, 9, 75.

Steinbach, M. (1964). The normal in cardiovascular diseases. Lancet, $2,1116$.

Symmers, W. St. C. (1956). Primary amyloidosis: a review. J. clin. Path., 9, 187. 